\title{
Climate Change and Climate Responsibility. Our Responsibility.
}

\author{
Øyvind Ravna* \\ UiT The Arctic University of Norway, Tromsø, Norway
}

The effects of climate change are becoming more visible all over the world, and few people still question whether it is man-made. Climate change is no longer just a question of melting ice and starving polar bears in the Arctic. Today we are seeing drought, overheating, forest fires, landslides, extreme rains and floods, all of which can be linked to a changing climate. Melting snow in the high mountains causing floods in the late fall - not the spring - is a specific example from Norway last year. Certain species of fish previously only found in temperate areas, which are now also being found in the Barents Sea, is another example from the Nordic sphere.

In 2015, the United Nations Member States unanimously endorsed the 2030 Agenda for Sustainable Development, which includes 17 Sustainable Development Goals (SDGs). The goals represent an urgent call for action by all countries, recognizing that ending poverty and other deprivations must go hand-in-hand with strategies that improve health and education, and reduce inequality - all while tackling climate change and the effort to preserve our oceans and forests. ${ }^{1}$

Developments after the endorsement of the 2030 Agenda, however, have not been progressing in the direction of its goals. The Intergovernmental Panel on Climate Change (IPCC), ${ }^{2}$ which is the UN's expert organ for assessing the science related to climate and climate change, recently came with strong warnings. In its 2018

1 United Nations, Sustainable Development Goals, https://sustainabledevelopment.un.org/ ?menu=1300 (06.02.2019).

2 The Intergovernmental Panel on Climate Change (IPCC) is the UN's body for assessing the science related to climate and climate change, established by the United Nations Environment Programme back in 1988 to provide the world society with a clear view on the current state of knowledge in climate change and its potential environmental impacts, https://www. ipcc.ch/about/ (06.02.2019).

\footnotetext{
^Correspondence to: Øyvind Ravna, email: oyvind.ravna@uit.no

(C) 2019 Øyvind Ravna. This is an Open Access article distributed under the terms of the Creative Commons Attribution-NonCommercial 4.0 International License (https://creativecommons.org/licenses/bv-nc/4.0/), allowing third parties to share their work (copy, distribute, transmit) and to adapt it, under the condition that the authors are given credit, that the work is not used for commercial purposes, and that in the event of reuse or distribution, the terms of this license are made clear.
} 
report Global Warming of $1.5{ }^{\circ} \mathrm{C}$, the IPCC alerts of the impact of global warming of $1.5{ }^{\circ} \mathrm{C}$ above pre-industrial levels and urges a global response to the threat of climate change and the need for sustainable development. Potential risks include increases in mean temperature in most terrestrial and ocean regions, extreme heat in many inhabited regions, heavy precipitation in several regions and the probability of drought and rainfall deficits in some regions. Climate-related risks to health, livelihoods, food security, water supply, human security and economic welfare are projected to increase with global warming of $1.5^{\circ} \mathrm{C}$, and consequently to increase further with $2{ }^{\circ} \mathrm{C} .{ }^{3}$

According to $C I C E R O$, Norway's leading institute for interdisciplinary climate research, a $2{ }^{\circ} \mathrm{C}$ warm-up will not only increase the likelihood of torrential rain, but also increase sea-level rise, threaten twice as many animal species with extinction, melt 2 million square kilometers of tundra, dramatically decrease fish stocks and world food production, and double the number of people who will have difficulty accessing clean water. ${ }^{4} \mathrm{~A}$ corresponding escalation of refugee flows northwards goes without saying.

At the Katowice Climate Change Summit in Poland in December 2018, the parties to the Paris Agreement, on overtime, came to a consensus on the Paris 'rule book' or how the agreement is to be implemented. However, many believe that this fragile consensus will be difficult to maintain.

As scholars and researchers, we have responsibilities. Since most of us who read Arctic Review work in the fields of law and social sciences, we perhaps have little to contribute to technologically based research and development to reduce emissions. Nor will many of us have the chance to participate in the preparation of international agreements, laws and regulations aimed at reducing the use of coal, oil or other fossil fuels. Nevertheless, we can contribute. We can influence academic communities, policy-makers and the public more generally through research, proposals and policy considerations for regulations and legislation that contribute to reduced emissions. Through research and publications, we can also highlight consequences of not acting.

Equally important, we can contribute on a personal level. For most individuals in the industrialized world, airplane flights represent probably the biggest single emission contribution to a negative climate budge - and they are the easiest to limit. With airplane travel, any positive benefit of our work is easily outweighed by red figures in our climate budget. Today we have excellent digital tools and equipment that enable us to communicate and talk together, almost as if we are in the same room, as well as to teach students overseas. Many scholars need little travel for field work;

3 IPPC, Special Report: Global Warming of $1.5^{\circ}$, Summary for Policymakers, https://www. ipcc.ch/sr15/chapter/summary-for-policv-makers/ (06.02.2019).

4 CICERO, 1,5 grader er mulig, men svært krevende, https:/www.cicero.oslo.no/no/posts/ nyheter/15-grader-er-mulig-men-svaert-krevende (06.02.2019). 
most of our sources for research come from archives, court reports, and other texts and documents that we find online or with the help of our good librarians or archivists. Yet we spend hours and hours on planes to meet at conferences, believing that it contributes in a positive way to democratic development, observance of human rights nationally and internationally, the protection of indigenous people, global stability and sustainability.

Instead of being at the forefront of acting, we risk being in the back row, making deeper ecological footprints than we fully comprehend today. My wish for the rest of 2019 - and for the coming years - is that we all spend some time thinking about our travels, asking ourselves if we really need to take that long-distance flight we are about to book for another conference. Instead, can we acquire knowledge and disseminate our research and findings in a more climate-friendly way? For example, through use of digital or other means of communication that do not require so much time in the air. If each of us can travel one or two less times by plane a year, we have already contributed in the right direction.

For those who are planning seminars and conferences, consider locations and organizing that minimizes the overall travel burden. If this causes disproportionate additional costs for those living in peripheral areas, consider whether their travel expenses could be included in the budgets. And there need not be a rule that research projects must include large conferences where participants log hundreds of flight hours, to receive funding from national research councils. Facilitating digital presentations and digital conference sessions, and encouraging researchers to present in these ways, is a good method for reducing emissions. Nor does this necessarily make presentations less exciting or less informative. For my own part I can hardly remember a more exciting presentation, and a more crowded auditorium, than when the former UN Special Rapporteur of Indigenous People James Anaya presented his report on the Sámi situation in the Nordic countries in Tromsø in 2011 - via Skype from Tucson, Arizona.

With such measures we can save both travel costs and time, and not least, reduce emissions. Then, with a clearer conscience, we can use our "personal climate quota" on gatherings where we really do need to meet and set time aside for face-to-face social contact that digitally facilitated interaction cannot fully replace. In this way, we can also contribute to a more sustainable and safer world for our children and the coming generations. 